\title{
PENERAPAN DINAMIKA ALAMIAH PADA LAGU-LAGU YANG TIDAK BERTANDA DINAMIKA
}

\author{
R.A. Dinar Sri Hartati ${ }^{1}$
}

Abstract

Music is expression in sound. Sound without expression is not music. In music we express the idea. Dynamic is a musical elemen, that has function to express the idea and the soul of the sound, so the sound can be music. This article gives a practical direction about how we can applicate dynamic in a musical composition naturally so the idea of music can we hear, feel, and enjoy.

Keywords: Dynamic, Music, Composition

\section{Pendahuluan}

Bunyi satu komposisi tidak serta-merta dapat disebut sebagai musik. Musik lebih dari bunyi. Musik adalah bunyi yang hidup. Sesuatu bunyi dapat menjadi musik, apabila bunyi tersebut memiliki ide. Ide musikal hanya dapat diekspresikan dan ditangkap serta dinikmati, apabila bunyi tersebut diberi jiwa sesuai dengan roh yang ada dalam ide tersebut. ${ }^{2}$ Dinamika adalah salah satu elemen musikal yang penting, yang dapat membantu mengekspresikan ide satu komposisi musikal, sehingga dapat ditangkap, didengar, serta dinikmati, sehingga bunyi dapat hidup dan menjadi musik.

Terdapat beberapa jenis dinamika musikal, antara lain seperti yang dikelompokkan oleh Perry Rumengan berikut yakni:

1. Dinamika volume yakni dinamika berdasar kuat lembutnya bunyi seperti piano (lembut), mezzoforte (agak kuat). Forte (kuat), dan lain-lain, termasuk dinamika proses seperti crescendo (berangsur-angsur menjadi kuat), decrescendo (berangsur-angsur menjadi lembut).

2. Dinamika register atau warna bunyi yakni dinamika berdasar warna suara instrumen, yang mana setiap instrumen memiliki warna sekaligus volumenya sendiri seperti Klarinet agak lembut, terompet yang tajam, tuba yang tebal, dan lain-lain.

\footnotetext{
${ }^{1}$ Dosen Program Studi Sendratasik dan Konsentrasi Musik Non Kependidikan Universitas Negeri Manado.

${ }^{2}$ Perry Rumengan, Musik Gerejawi Kontekstual Etnik. Jakarta: Panitia Konggres Kebudayaan Minahasa, 2009, 11
} 
3. Dinamika sound-mass yakni dinamika yang terjadi akibat masa bunyi, dimana kalau masa bunyi besar maka otomatis bunyi akan kuat dan masa bunyi sedikit, maka bunyi tidak terlalu kuat. ${ }^{3}$

Secara umum, dinamika komposisi untuk Paduan Suara, selain dapat dipengaruhi oleh gerak melodi, ritme, tempo, progres akor, gaya dan bentuk iringan, namun terlebih juga oleh isi dan emosi syair. ${ }^{4}$

Artikel ini dimaksudkan untuk memberikan petunjuk praktis penerapan dinamika pada satu lagu. Petunjuk ini akan disertai dengan sejumlah contoh dan diharapkan dengan beberapa contoh penerapan ini, para interpretator dapat mempraktikkan menerapkan dinamika pada sebuah lagu secara alamiah, sekalipun lagu tersebut tidak memiliki tanda-tanda dinamika. Beberapa Pedoman Praktis dan Alamiah. ${ }^{5}$

1. Lagu yang berisi doa atau perenungan atau kisah sedih atau liris atau pun melankolis umumnya diekspresikan dengan dinamika lembut.

2. Lagu yang berisi ceritera atau kisah atau menceritakan tentang sesuatu secara umum agak kuat, tetapi di tengah lagu sering terdengar dinamika lembut atau pun kuat untuk mendramatisasikan isi ide. Dinamika tersebut sesuai dengan arti dan emosi syair.

3. Lagu yang mengajak atau memanggil atau menyerukan atau gembira atau marah sering agak kuat, bahkan pada bagian tertentu terdengar sangat kuat.

4. Awal kalimat melodi menuju tengah kalimat atau akhir kalimat anteseden biasanya dinamika menaik atau crescendo dan sebaliknya dari kalimat tengah menuju akhir kalimat atau konsekuen dinamikanya menurun atau menjadi lembut.

5. Tiga nada yang sama berturut-turut dinyanyikan sedikit crescendo, tetapi apabila sesudah tiga nada tersebut diikuti dengan nada yang lebih rendah, maka dinamika agak sedikit menurun. Sebaliknya bila sesudah tiga nada tersebut diikuti dengan nada yang lebih tingggi, maka crescendo dilanjutkan.

\footnotetext{
${ }^{3}$ Periksa Perry Rumengan, "Penerapan Dinamika pada Lagu Yang Tidak Bertanda Dinamika" makalah yang disampaikan pada seminar nasional yang diadakan Lembaga Pengembangan Pesparawi Nasional di Bogor, 28 Mei 2012.

${ }^{4}$ Bandingkan dengan Secunda Practica yang dikemukakan Claudio Monteverdi dengan teknik word Painting, di mana gerakan melodi mengikuti arti, fungsi, dan gerak emosi syair, demikian juga dinamika. Lihat, Victor Ribeiro Rangel, Baroque Musi, (London: Collier McMillan, 1981), passim.

${ }^{5}$ Perry Rumengan, “ Memberi Jiwa pada Sebuah Lagu”, makalah yang disampaikan dalam Workshop Paduan Suara dalam materi Choir Clinic di Jemaat Sario Kotabaru Manado 29 Agustus 2003.
} 
6. Apabila terdapat nada yang ditahan dan diikuti dengan nada yang lebih tinggi, maka dinamikanya crescendo, sebaliknya apabila diikuti dengan nada yang lebih rendah, maka dinamika crescendo.

7. Apabila rangkaian nada naik, baik tersurat atau tersirat, maka dinamika crescendo, sebaliknya menurun, baik tersurat maupun tersirat, maka dinamika decrescendo.

8. Terkadang dinamika terbentuk dari masa bunyi seperti apabila yang membawakan melodi hanya satu suara atau satu alat, maka otomatis komposer menginginkan dinamika tidak kuat. Sebaliknya apabila komposer ingin dinamika yang lebih kuat, baik bergradasi maupun secara langsung, biasanya komposer menambah dengan suara lain sehingga dinamika menjadi lebih kuat akibat massa bunyi semakin banyak. Demikian sebaliknya apabila masa bunyi menurun, maka dinamika akan mengecil atau melembut.

Untuk dapat memahami dan menerapkan dinamika secara tepat pada satu komposisi musikal, secara khusus untuk komposisi Paduan Suara, maka seorang dirigen atau pelatih atau interpretator harus memulainya dengan menerapkan analisis secara tepat dan cermat. Analisis yang tepat dan cermat, bukan hanya diterapkan pada elemen melodi, tetapi pada seluruh aspek kompositoris yang ada, termasuk yang sangat penting adalah elemen syairnya. ${ }^{6}$

Berikut ditunjukkan satu tabel penerapan dinamika sesuai dengan gerakan melodi, konteks syair, interaksi elemen-elemen musikal sebagai bagian dari aspek kompositoris sebuah lagu.

\begin{tabular}{|c|c|c|c|c|}
\hline No & DINAMIKA & $\begin{array}{c}\text { BENTUK, GERAKAN, } \\
\text { STATUS RANGKAIAN } \\
\text { NADA/MELODI }\end{array}$ & KONTEKS SYAIR & $\begin{array}{l}\text { KONTEKSTUAL } \\
\text { ATMOSFIR } \\
\text { BUNYI AKIBAT } \\
\text { INTERAKSI } \\
\text { ELEMEN- } \\
\text { ELEMEN }\end{array}$ \\
\hline 1. & $\begin{array}{l}\text { pp. } \\
\text { (pianissmo) }\end{array}$ & \multirow{2}{*}{$\begin{array}{l}\text { - Nada rendah, terlebih } \\
\text { dalam konteks lagu } \\
\text { khidmat. } \\
\text { - Nada rendah dalam } \\
\text { konteks normal dan }\end{array}$} & \multirow{2}{*}{$\begin{array}{l}\text { - Doa, Permohonan. } \\
\text { - Mengharukan. } \\
\text { - Keluhan. } \\
\text { - Sedih. }\end{array}$} & \\
\hline 2. & p. (piano) & & & \\
\hline
\end{tabular}

\footnotetext{
${ }^{6}$ Bandingkan, Andew J. Broekma, The Music Listener, Iowa: Wm. C. Brown Company Publishers, 1978, p. 29-137.; Daniels, Wagner, Music, New York: Holt, Rinehart and Winston, 1975, 4-53.; Joseph Kerman, Listen, New York: Worth Publishers, Inc., 1980, 4-65.
} 


\begin{tabular}{|c|c|c|c|c|}
\hline & & $\begin{array}{l}\text { tidak dalam penekanan } \\
\text { khusus. }\end{array}$ & \multirow[b]{2}{*}{$\begin{array}{l}\text { - Rintihan dalam } \\
\text { melodi yang rendah. } \\
\text { - Belaian. } \\
\text { - Kerinduan. } \\
\text { - Kasih. } \\
\text { - Teks yang perlu } \\
\text { diperhatikan, untuk } \\
\text { mendramatisasi-kan } \\
\text { isi teks. } \\
\text { - Ratapan. } \\
\text { - Kata yang diulang, } \\
\text { yang dibuat kontras } \\
\text { dengan kata yang } \\
\text { sama pada bagian } \\
\text { sebelumnya atau } \\
\text { sesudahnya, yang } \\
\text { dinamikanya lebih } \\
\text { kuat. } \\
\text { - Pengasihan. } \\
\text { - Hasutan. }\end{array}$} & \\
\hline 3. & $\begin{array}{l}\text { Mp. } \\
\text { (mezzopiano) }\end{array}$ & $\begin{array}{l}\text { Konteks lembut, tetapi } \\
\text { dalam nada-nada } \\
\text { tinggi. Ini sebagai } \\
\text { konsekuensi dari } \\
\text { support yang diberikan } \\
\text { dalam vokal. }\end{array}$ & & \\
\hline 4. & $\begin{array}{l}\begin{array}{l}\text { Mf. } \\
\text { (mezzoforte) }\end{array} \\
\end{array}$ & & \multirow{4}{*}{$\begin{array}{l}\text { - } \text { Ajakan. } \\
\text { - Rintihan dalam } \\
\text { - } \text { Selodi yang tinggi. } \\
\text { - Pujian, Teriakan. } \\
\text { - Gegap-gempita. } \\
\text { - Kemarahan. } \\
\text { - Gempar dan } \\
\text { mengejutkan. } \\
\text { - Cerita atau kisah. }\end{array}$} & \multirow{4}{*}{$\begin{array}{l}\text { - Lompatan nada, } \\
\text { baik ke atas atau } \\
\text { pun ke bawah. } \\
\text { - Tuti, atau massa } \\
\text { bunyi yang lebih } \\
\text { banyak dan lebih } \\
\text { tinggi. } \\
\text { - Penggunaan } \\
\text { instrumen yang } \\
\text { bertimbre } \\
\text { nyaring dan kuat. }\end{array}$} \\
\hline 5. & f. (forte) & & & \\
\hline 6. & $\begin{array}{l}\text { ff. } \\
\text { (fortissimo) }\end{array}$ & & & \\
\hline 7. & $\begin{array}{l}\text { Sfz. } \\
\text { (sforzando) }\end{array}$ & $\begin{array}{l}\text { - Nada tinggi, atau } \\
\text { puncak gerakan nada, } \\
\text { terlebih apabila } \\
\text { terdapat kata, yang } \\
\text { memiliki arti khusus, } \\
\text { dan yang memerlukan } \\
\text { penekanan. Hal ini } \\
\text { berhubungan dengan } \\
\text { word painting. } \\
\text { - Nada yang ditahan dan } \\
\text { diikuti dengan gerakan } \\
\text { melodi yang menaik, } \\
\text { baik tersirat, maupun } \\
\text { tersurat. }\end{array}$ & & \\
\hline 8. & Crescendo & $\begin{array}{l}\text { - Melodi naik, baik } \\
\text { tersirat, maupun } \\
\text { tersurat. } \\
\text { - Awal kalimat menuju } \\
\text { tengah kalimat atau } \\
\text { antecedent. } \\
\text { - Tiga nada yang sama } \\
\text { berturut-turut apalagi } \\
\text { yang diikuti dengan } \\
\text { nada berikutnya yang } \\
\text { lebih tinggi. }\end{array}$ & $\begin{array}{l}\text { - Teks berulang-ulang } \\
\text { yang diikuti dengan } \\
\text { gerakan melodi yang } \\
\text { terus menaik. } \\
\text { - Kalimat yang } \\
\text { mendesak dan } \\
\text { mengajak. }\end{array}$ & $\begin{array}{l}\text { Antecedent pada } \\
\text { tingkatan yang } \\
\text { lebih tinggi. } \\
\text { - Penerapan teknik } \\
\text { moving forward. }\end{array}$ \\
\hline
\end{tabular}




\begin{tabular}{|c|c|c|c|c|}
\hline & & $\begin{array}{l}\text { - Nada yang ditahan dan } \\
\text { diikuti dengan nada } \\
\text { yang lebih tinggi. } \\
\text { - Nada yang ditahan dan } \\
\text { diikuti dengan gerakan } \\
\text { melodi yang menaik, } \\
\text { baik tersirat, maupun } \\
\text { tersurat. }\end{array}$ & & \\
\hline 9. & Decrescendo & $\begin{array}{l}\text { - Melodi turun, baik } \\
\text { tersirat, maupun } \\
\text { tersurat. } \\
\text { - Awal kalimat menuju } \\
\text { akhir kalimat atau } \\
\text { consequent. } \\
\text { - Tiga nada yang sama } \\
\text { berturut-turut apalagi } \\
\text { yang diikuti dengan } \\
\text { nada berikutnya yang } \\
\text { lebih rendah. } \\
\text { - Nada yang ditahan dan } \\
\text { diikuti dengan nada } \\
\text { yang lebih rendah. }\end{array}$ & $\begin{array}{l}\text { - Teks berulang } \\
\text { dengan gerakan nada } \\
\text { yang terus-menerus } \\
\text { menurun. } \\
\text { - } \text { Teks berulang-lang } \\
\text { diikuti gerakan nada } \\
\text { menurun, dan emosi } \\
\text { keputusasaan. }\end{array}$ & $\begin{array}{l}\text { - Antecedent pada } \\
\text { tingkat yang } \\
\text { lebih rendah. }\end{array}$ \\
\hline
\end{tabular}

Contoh Penerapan Dinamika pada Lagu Vokal dan Paduan Suara, yang Tidak Bertanda Dinamika

AGUNGLAH NAMA TUHAN

$l=D$ 3/6. Agung, angah, jangan terla1u tebar (N.). 84-92)

Lagu : Apol1 Bala

Syaiz: Apoli Bala

Arsa ; Apoli Bala

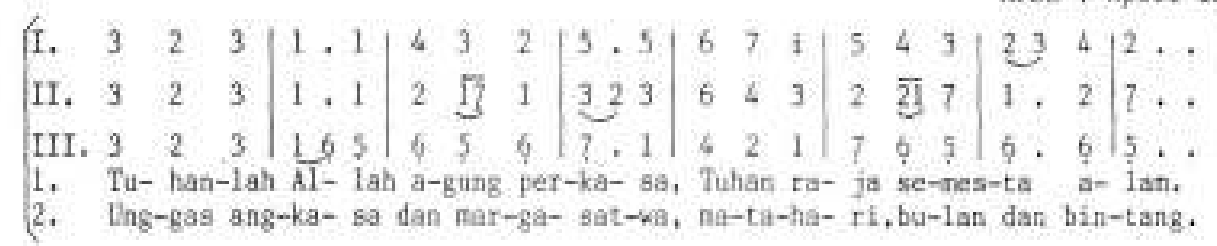

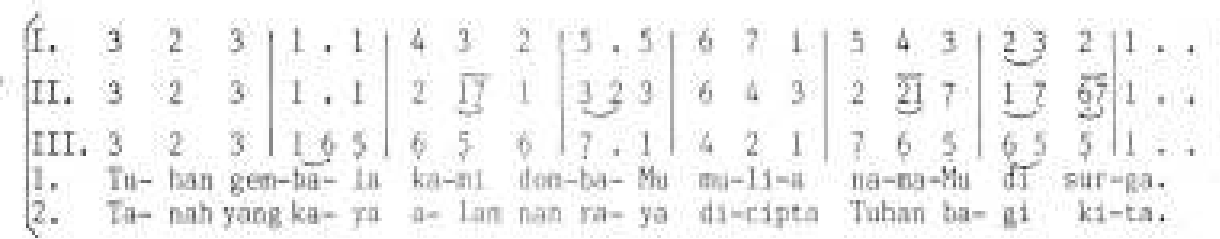

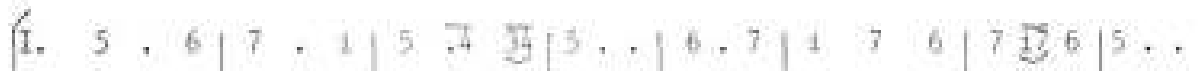

II. 3 \begin{tabular}{ll|lll|lll|lllllll|lllll}
3 & 1 & 5 & 4 & $\overline{34}$ & 3 & $\overline{21}$ & $\overline{3}$ & 3 & $\ldots$ & 6 & 4 & 3 & 5 & $\overline{34}$ & 53 & 4 & $5 .$.
\end{tabular}

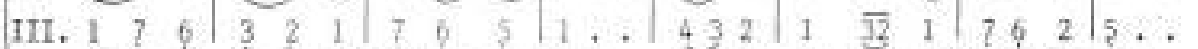

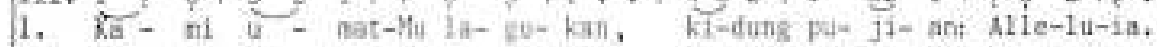

2. Na - na Tu - han ki-tn sen-bah, ka- sih cin-ta- Nya kita pu-ja.

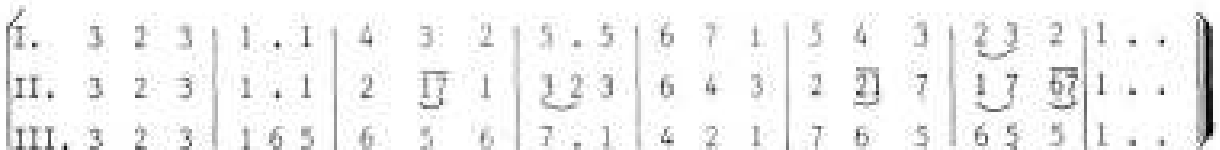

1. Se-ga-1a bäng-sa no-nyen-bah Di- kau Iuhur na-na-Mu di bu- bi-a.

2. Ma-ri ber-naz-nur de-ngan re- ba- ne untuk ne- na-syurkan na- ma-Nya. 
Secara umum lagu AGUNGLAH NAMA TUHAN menceritakan keagungan Tuhan, maka sebaiknya lagu ini tidak dibawakan secara terlalu lembut atau lembut, karena dari teks ini tersirat rasa kebanggaan dan keyakinan. Sebaiknya, pada bagian awal dimulai dengan dinamika mezzoforte. Sesuai dengan rumusan yang dikemukakan pada bagian awal, di mana apabila ada gerakan melodi yang menaik, maka dianjurkan untuk membuat crescendo. Itu sebabnya, pada kalimat 'Tuhanlah Allah Agung Perkasa, Tuhan Raja' sebaiknya dibuatkan dinamika crescendo dan seterusnya menuju kalimat 'Semesta Alam' akan menjadi decrescendo mengingat nadanya menurun.

Hal yang sama terjadi pada kalimat 'Tuhanlah Gembala Kami DombaMu Mulia' menjadi crescendo, karena melodinya naik dan dilanjutkan dengan dinamika decrescendo pada kalimat 'NamaMu di Surga' karena melodinya menurun. Pada kalimat di bawahnya yakni 'Kami Umat' menjadi crescendo, karena nada menaik dan segera dilanjutkan dengan decrescendo pada kata 'Mu Lagukan', karena melodi menurun. Pada kalimat 'Kidung Pujian: Alleluia' sangat kuat untuk diterapkan dinamika crescendo, selain melodi menaik, juga diikuti dengan modulasi sementara, dan ujung kalimat tersebut merupakan ujung kalimat antecedent. Seterusnya dapat dianalogikan, dan akhirnya menuju akhir lagu menjadi decrescendo.

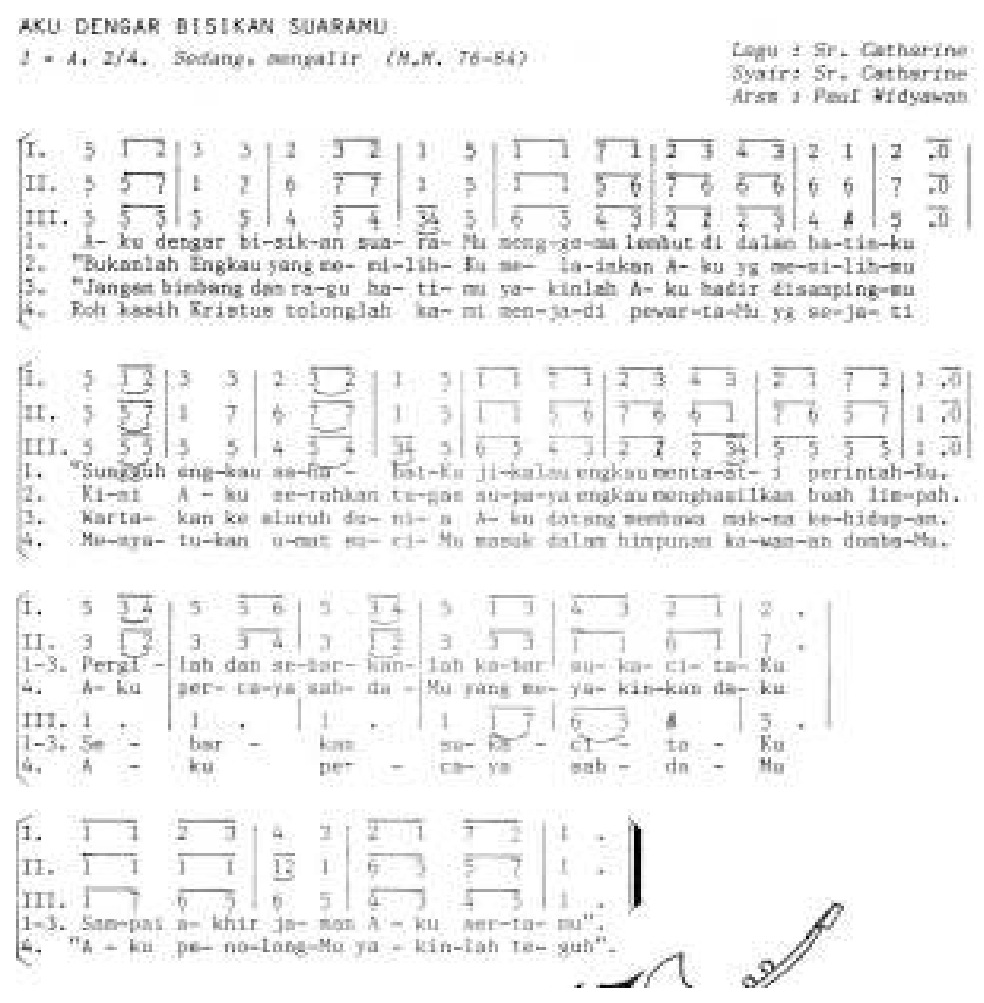


Dalam lagu AKU DENGAR BISIKAN SUARAMU secara umum konteks isi teks pada bagian pertama mengisahkan, bagaimana seseorang mendengar bisikan Tuhan dalam hatinya, selain harus memberi perhatian, juga suara tersebut perlu dinikmati, itulah sebabnya pada bagian awal lagu ini lebih cocok untuk menggunakan atau memulainya dengan dinamika lembut. Pada kalimat 'Aku Dengar Bisikan' diterapkan dinamika crescendo, karena melodinya menaik, dan segera dibuat decrescendo pada kalimat 'SuaraMu' mengingat melodinya menurun. Adapun pada kalimat berikutnya yakni pada kalimat 'Menggema Lembut di Dalam Batinku' menjadi crescendo karena terdapat melodi menaik secara tersirat, juga diikuti dengan modulasi sementara dan menuju kalimat antecedent. Crescendo di tempat ini tidak terlalu kuat dan menjadi forte mengingat konteksnya masih lembut, jadi sebaiknya crescendonya sampai taraf mezzoforte saja.

Pada bagian kedua konteks teks berisi ajakan, seruan dan menyuruh untuk menyebarkan kabar suka cita ini. Selain kalimat tersebut merupakan kalimat perintah, juga sabda tersebut sangatlah menggembirakan hati orang beriman. Oleh karena itu, dalam bagian ini dinamika yang tepat sebaiknya menggunakan dinamika forte diimbangi dengan gerakan crescendo dan decrescendo sesuai dengan gerakan melodi, dan berakhir dengan decrescendo pada akhir lagu. Decrescendo di akhir lagu ini juga harus diikuti dengan rasa puas dan sangat senang, sebab kata-kata ini sangat menghibur. Kalimat ini menjadi pegangan dalam tugas utusan tersebut, demikian dimulai dengan crescendo pada kata 'Sampai Akhir Jaman' dan diakhiri dengan decrescendo pada kalimat 'Aku sertaMU.' Demikian apabila diterapkan dinamika dalam lagu tersebut, maka akan menjadi seperti berikut. 
AKU DENGAR BISIKAN SURRAMU

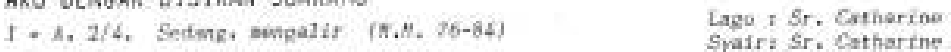

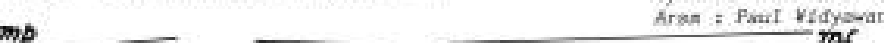

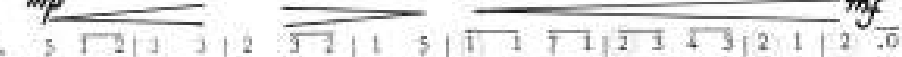

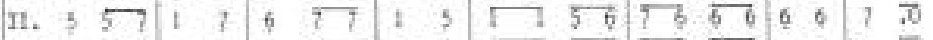

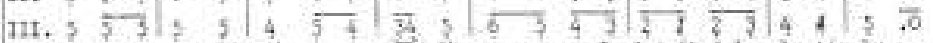

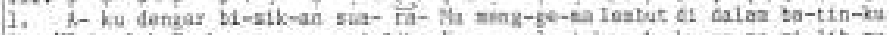

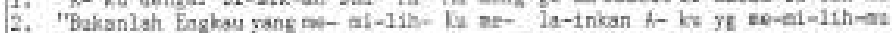

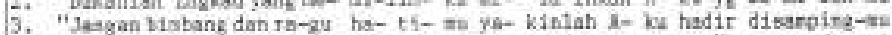

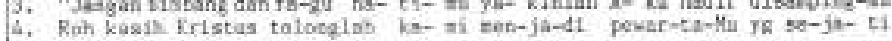

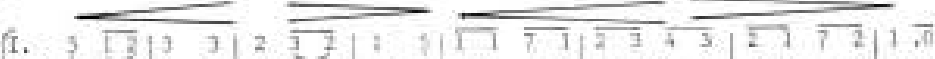

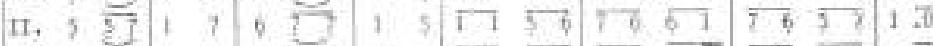

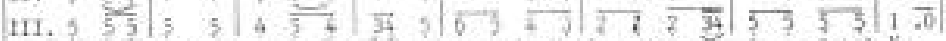

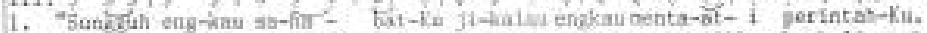

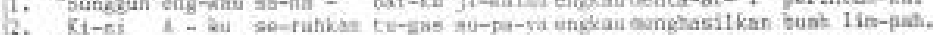

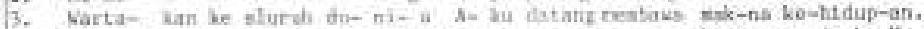

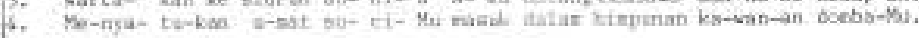

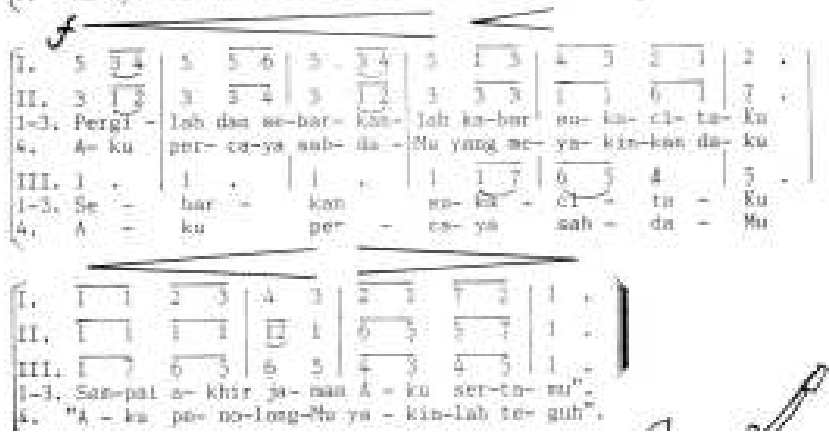

NYANYT LAGU BAEU

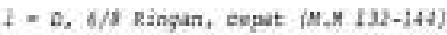

Lagu i Igv.de sutter Syairt BKE Rolsase arsen F Y.E. Mrier / Pagl kiduawia

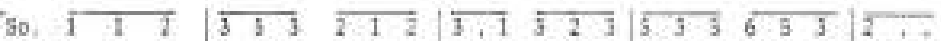

1. Nyanyi is- gu do-ru st-1u-roh tu- ei fu-jilah Tutan yu-ji na-ba- Sya

2. A- ging-lak Tulas bet-ksti ra- na-kys Bu-ei lagit dipogang tangk-Nya

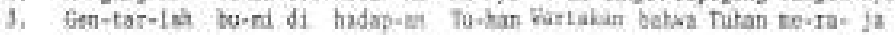

I.

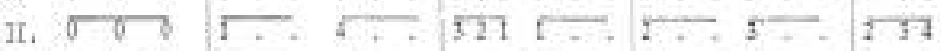

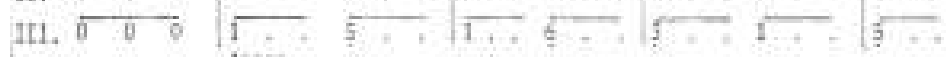
Aasas.
}

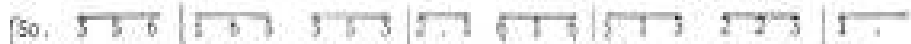

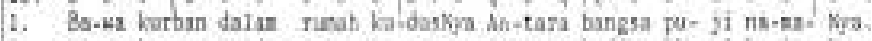

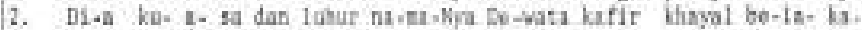

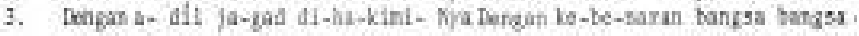

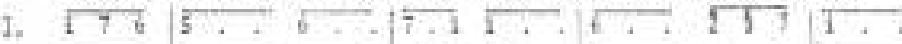

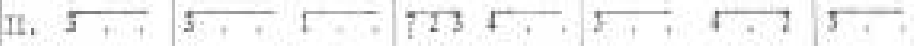

111. Asaras

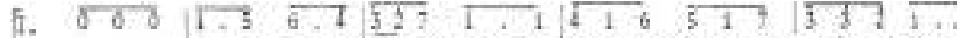

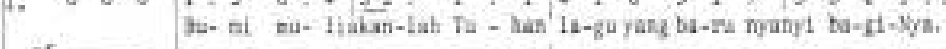

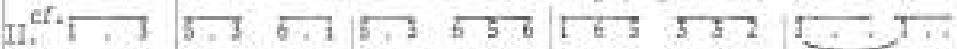

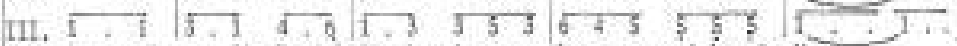

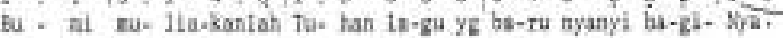


Dalam lagu NYANYI LAGU BARU konteks teks melukiskan kegembiraan. Teks mengajak untuk bergembira dan menyanyikan lagu baru bagi Tuhan. Sesuai dengan konteks ini, sebaiknya dimulai dengan suasana kuat, akan tetapi dianjurkan tidak langsung dengan forte agar di tengah kita memiliki sedikit gerak untuk membuat crescendo atau pun decrescendo. Pada kalimat awal 'Nyanyi Lagu Baru Seluruh' dibuat crescendo, karena terdapat melodi menaik secara tersirat dan langsung diikuti dengan decrescendo pada kata 'Bumi,' sebab ada gerakan melodi menurun dari nada 3 (mi) yang ditahan menuju nada 1 (do) yang lebih rendah.

Pada kalimat berikut yakni 'Pujilah Tuhan Pujilah NamaNya' dirasa tepat untuk menerapkan dinamika crescendo, selain karena melodi bergerak naik secara tersirat kalimat ini terdapat pada bagian akhir sementara atau antecedent. Seterusnya pada kata 'Bawa' crescendo, karena melodi menaik, tetapi langsung dibuat gerakan decrescendo mengingat dalam kalimat 'Kurban Dalam Rumah KudusNya' terdapat melodi menurun secara tersirat. Begitu juga pada bagian berikutnya dinamika crescendo pada kalimat 'Antara Bangsa Puji’ karena melodi menaik secara tersirat dan dilanjutkan dengan decrescendo pada kalimat 'NamaNya.' Selain karena melodi menurun secara tersirat juga kalimat tersebut pada akhir kalimat pertama (consequent).

Seterusnya pada akhir lagu berisi isi seruan tersebut, sebab itu pantas untuk diterapkan dinamika kuat, bahkan sampai forte, dan tentunya diikuti dengan gerakan decrescendo menuju akhir lagu ini (consequent). Demikian penerapan dinamika untuk lagu ini dapat dilihat seperti dipaparkan pada bagian berikut.

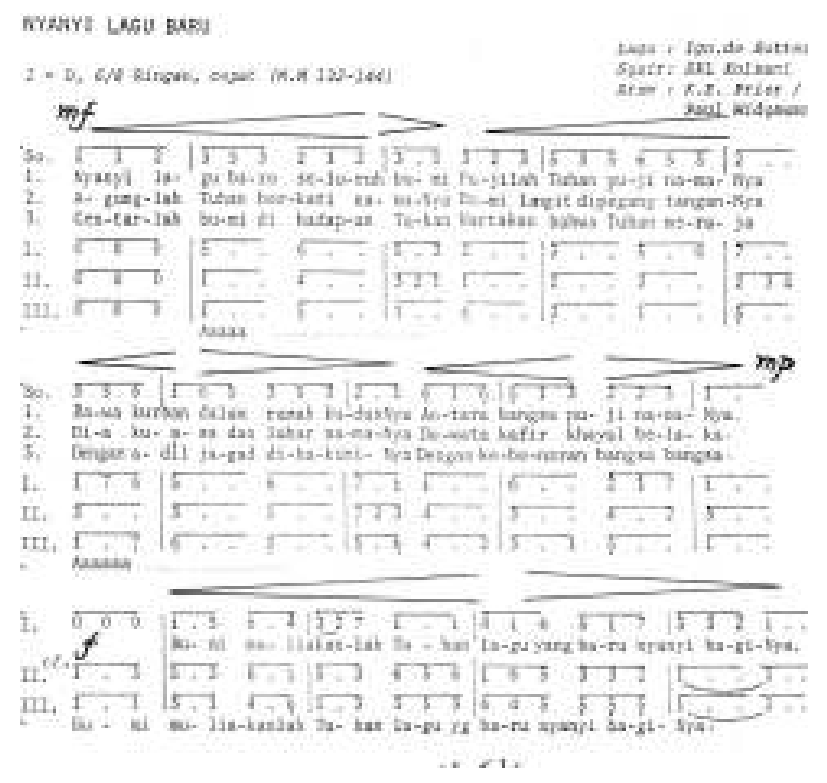




\section{YA YESUS AKU NAIITIKAN}
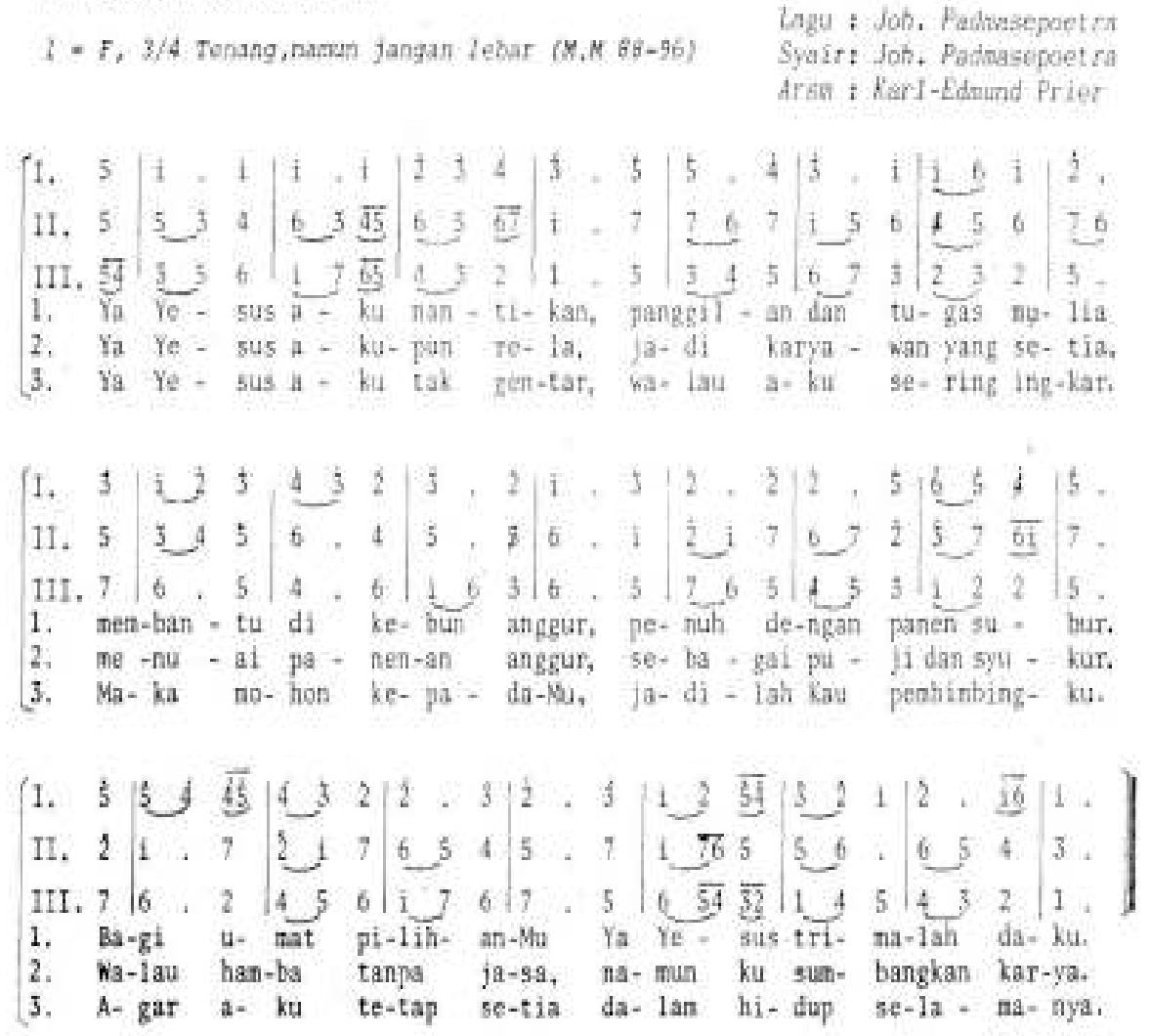

(Raset PYL 12-B)

Dalam lagu YA YESUS AKU NANTIKAN teks menceritakan satu percakapan orang beriman dengan Yesus, di mana orang tersebut (beriman) menawarkan kerelaan yang sungguh untuk menjadi pelayan Kristus, berpartisipasi dalam karya keselamatan Allah. Suasana ini tentunya tidak terlalu lembut, sebab apabila lembut akan terkesan seperti menghasut. Akan tetapi dalam teks ini tawaran ini diikuti dengan keyakinan dan rasa gembira, maka sebaiknya dinamika dimulai dengan mezzoforte. Dinamika ini seterusnya diikuti dengan crescendo, hingga pada kata 'Panggilan.' Karena dinamika ini dimulai dengan mezzoforte, maka secara logis pada puncak crescendonya dapat mencapai forte. Pada kalimat berikutnya perlu diikuti dengan decrescendo karena terdapat melodi yang bergerak menurun secara tersirat.

Pada kalimat 'Penuh Dengan Panen Subur' mendapat dinamika crescendo, selain karena terdapat melodi menaik secara tersirat, dan modulasi sementara, juga karena bagian itu merupakan akhir bagian antecedent. Pada bagian berikut dengan kalimat 'Bagi Umat PilihanMU Ya Yesus Trimalah Daku' pantas mendapat dinamika 
kuat, selain karena berisi keyakinan sebagai orang pilihan Allah, juga karena nadanya berada di tinggi. Demikian dinamika lagu ini secara terperinci dapat dilihat pada bagian yang dipaparkan berikut.

\section{YA YESUS AKU NANTIKANA}

$$
1=F, 3 / 4 \text { renang, narken jangen lebar (M, M 89-96) }
$$

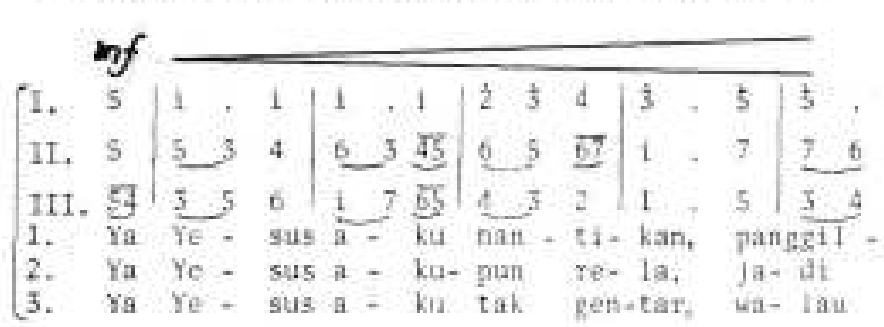

Lagu : Joh. Padnensopoetra Syair: Jah. Padrasepoecra Arsia : Rar1-Eidnund Prier

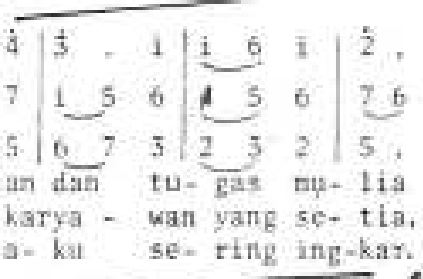




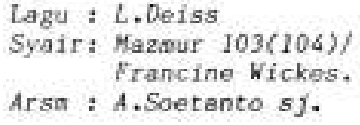

Refren: (didehului oleh Solo/Koor, diulangi bersama umat)

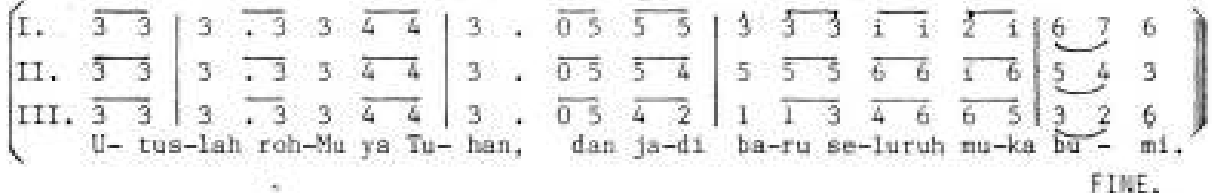

Ayat: Mazaur $102 \quad 4 / 4,5 / 4$

I. $\overline{33}|6 \overline{56} \overline{76} \overline{56}|=110$

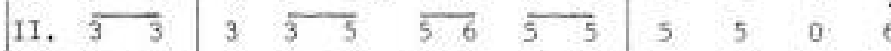

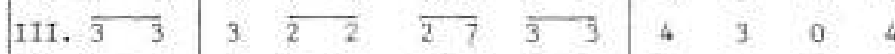

IV. $\overline{3} \mid \begin{array}{llllllll} & 1 & 7 & 55 & 1 & 1 & 1 & 0\end{array}$

1. AI- lah-ku (na) nasia-Mu hen-dak ku - pu - j1 Eng -

2. Ya Tu-han (ber) berselubung-kan ca - ha - ya Ba -

3. Fir-man-Ma (di) disampaikan o-1eh a - ngin A -

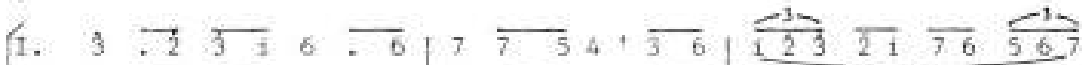

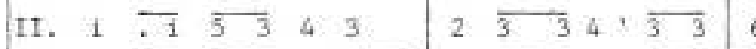

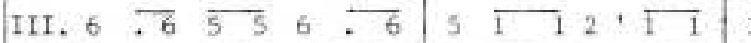

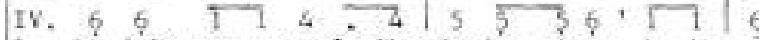

1. kau(a)a-nat agung(berberdandán sinar ke-be-sar-

2. gatf $j u)$ jubah ra-ja( $1 \mathrm{a})$ langit Kau pasang ba-gai ke-

(3. pi (vg)yg berkobar (Lun)tunduk pa-da-Na ba-gai han-

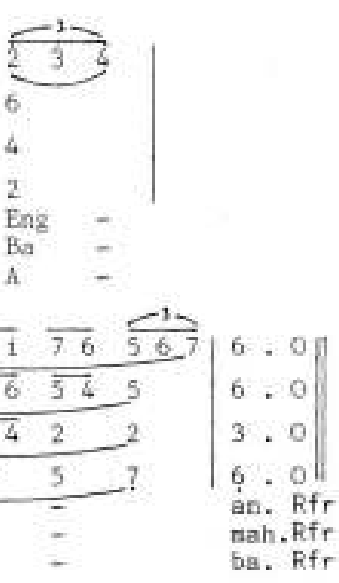

(Kaser PML 21-A)

NE: Pola lagu Solo untuk ayat mazour laing $36 \ldots 561 . / 475 \ldots 676.11$

Dalam lagu UTUSLAH ROHMU YA TUHAN, teks menunjukkan suasana permohonan agar Allah mengutus RohNya. Permohonan dan melodi yang terletak pada nada yang agak rendah, sangat kuat diekspresikan dengan dinamika lembut. Adapun pada kalimat 'Dan Jadi Baru Seluruh Muka Bumi' menjadi sangat kontras, bahkan menjadi kuat, kerena terdapat lompatan nada pada nada-nada tinggi. Selain itu, teks sangat kuat menerangkan, bahwa apabila Roh Allah turun, maka dunia akan menjadi baru. Selain itu juga, kalimat tersebut merupakan refrein dari lagu ini.

Pada bagian berikut dinamika tidak terlalu kuat mengingat kalimat-kalimat berikut merupakan ayat dari lagu ini. Untuk rumusan dinamika lagu ini secara keseluruhan mengikuti gerakan melodi. Demikian dinamika lagu ini dapat dilihat secara jelas seperti dipaparkan pada bagian berikut. 
UTUSLAH BOHEU YA TUHAN

$I$. the $\alpha / 4$ Sedat $(\pi, \%, 72-50)$

Lakn: L.Deisa

Syajrt Mazmur toy (10s)

Francine Nirkes.

Arsa + A. Soerante sy.

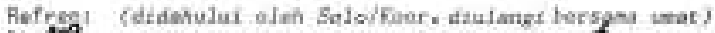

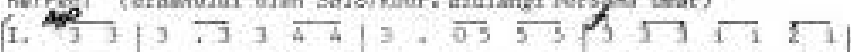

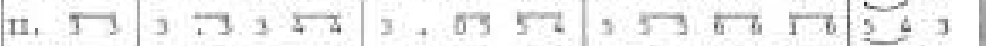

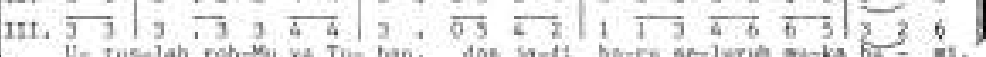

Ine FJae.

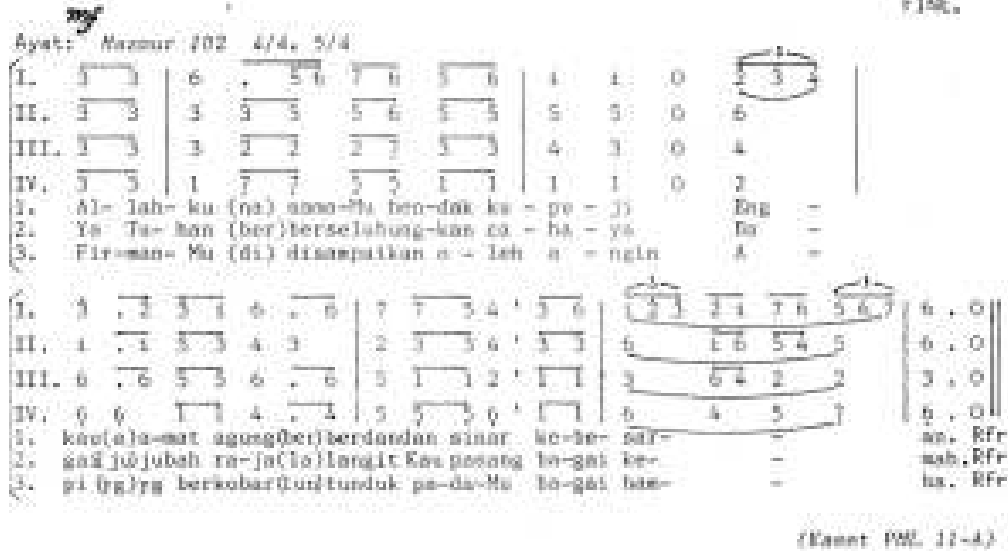

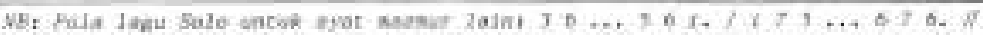

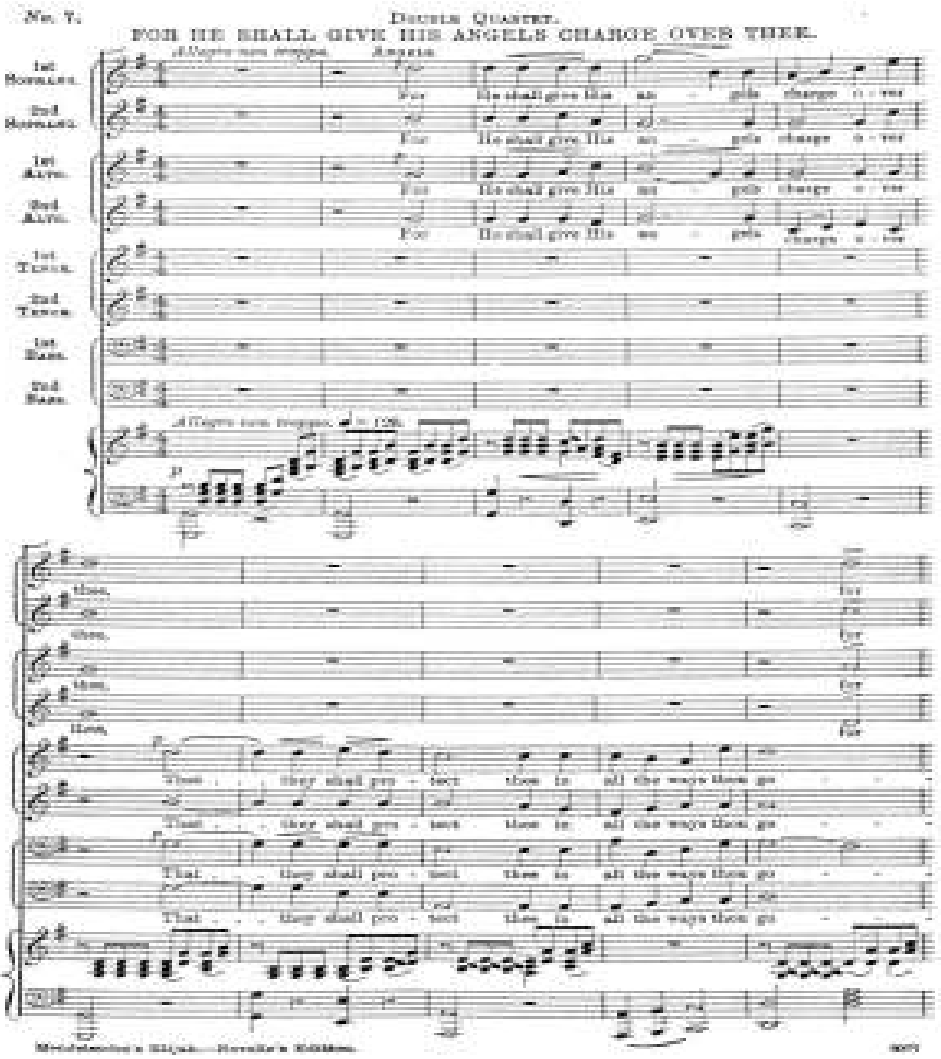


Dalam contoh lagu di atas terlihat fenomena lain, yakni dalam kalimat he shall give His angels terlihat tanda dinamika crescendo dan decrescendo. Dalam kalimat tersebut terdapat nada ' $D$ ' sebanyak empat kali diikuti dengan nada ' $G$ ' di tempat yang lebih tinggi pada suku kata 'an'. Dalam kasus ini tampak, bahwa apabila ada nada yang sama berurutan sebanyak tiga kali atau lebih, maka akan dinyanyikan secara crescendo apalagi diikuti dengan nada yang lebih tinggi. Berikut contoh lagu "Malam Sjahdu"
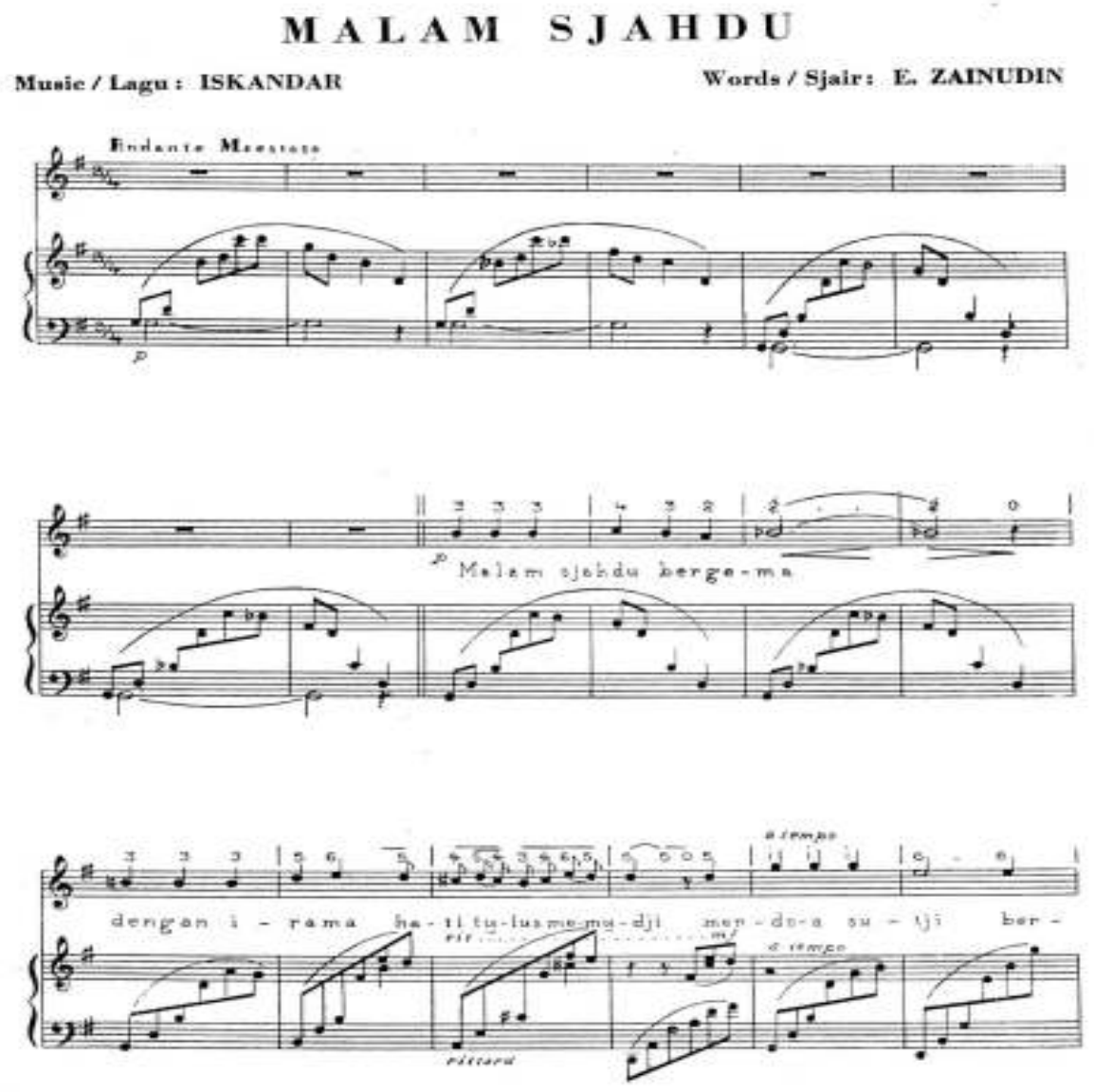

Dalam lagu di atas tampak juga dinamika crescendo-decrescendo pada suku kata 'ma' dari kata bergema dengan nada 'Bes' yang ditahan hingga lima hitungan. Dalam kasus ini dapat dilihat apabila nada yang sama ditahan agak panjang, biasanya pencipta ingin membuat sedikit variasi dinamika, dalam hal ini crescendo dan decrescendo. Hal ini dimaksudkan agar bunyi tersebut terdengar dinamis dan tidak statis. 


\section{Dinamika Kontekstual.}

Selain dinamika-dinamika seperti dikemukakan di atas, terdapat juga apa yang disebut dengan dinamika kontekstual. Maksud dari dinamika kontekstual adalah dinamika, yang bukan dalam bentuk piano atau forte atau crescendo atau pun decrescendo, tetapi dalam bentuk saran suasana yang diusulkan komposer, yang biasanya ditulis komposer pada bagian awal lagu seperti, maestoso yang berarti hikmat, majesty yang berarti agung, con brio yang berarti dengan hidup, con fuoco yang berarti berapi-api, mormorendo yang berarti bernyanyi seperti orang bersungut tidak jelas. Biasanya dinamika seperti ini sangat jelas terlihat dari ide syair. Ide-ide tersebut seperti doa, renungan, rayuan, seruan, memuji, menyembah, mengajak, menyatakan keyakinan, bercerita, dan lain sebagainya.

\section{Kepustakaan}

Broekma, Andrew J., 1978. The Music Listener, Iowa: Wm. C. Brown Company Publishers.

Daniels and Wagner, 1975. Music, United States of America: Holt, Rinehart and Winston.

Kerman, Joseph, 1980. Listen, New York: Worth Publishers, Inc.

Pusat Musik Liturgi, 1990. Madah Bakti, Yogyakarta: PML.

Rangel, Victor-Ribeiro, 1981. Baroque Music, London: Collier McMillan.

Rumengan, Perry, 29 Agustus 2003. “Memberi Jiwa pada Sebuah Lagu”, makalah yang disampaikan dalam Workshop Paduan Suara dalam materi Choir Clinic di Jemaat Sario Kotabaru Manado.

, 2009 Musik Gerejawi Kontekstual Etnik, Jakarta: Panitia Konggres Kebudayaan Minahasa.

,28 Mei 2012. "Penerapan Dinamika pada Lagu Yang Tidak Bertanda Dinamika" makalah yang disampaikan pada seminar nasional yang diadakan Lembaga Pengembangan Pesparawi Nasional di Bogor. 


\section{Data Diskografi.}

Untuk dapat lebih melengkapi referensi untuk artikel ini dapat dilihat juga dalam sejumlah repertoir seperti:

1. Sejumlah Lieder yang karya Frans Schubert.

2. Oratorio Mesiah dari J. F. Handel, die Jahrezeiten dan die Schopung dari J. Haydn.

3. Sejumlah repertoir mulai akhir abad Tengah hingga akhir jaman Romantik. Disarankan untuk melihat repertoir pada sekitar jaman ini mengingat pada repertoir-repertoir jaman moderen banyak komposer imgin mencari kemungkinan atmosfir baru sehingga terkada tidak alamiah karena sengaja untuk membuat beberapa surprise atau kontras.

4. Untuk lagu-lagu contoh dalam tulisan ini sebagian dapat dilihat dalam buku Madah Bakti, buku nyanyian umat Gereja Katolik, terbitan Pusat Musik Liturgi Yogyakarta. 